\title{
Africa Publishing Innovation Fund (APIF): Ideas to keep African Children learning and communities connected
}

\author{
Bodour Al Qasimi $^{1}$
}

Accepted: 22 June 2021 / Published online: 6 July 2021

(c) The Author(s), under exclusive licence to Springer Science+Business Media, LLC, part of Springer Nature 2021

\begin{abstract}
In 2019, an estimated 100 million African school-age children were designated 'outof-school', the highest numbers in the world. COVID-19 has dramatically worsened that already bleak picture because school closures have cut off any children who cannot access education remotely. Though the new figure is not yet known, it is clear that a generation of children will fall by the wayside unless decisive steps are taken to address the systemic, infrastructural and cultural hurdles that are preventing African children from learning. That would be a huge setback for African development, with potentially disastrous consequences in years to come. In 2021, its second year of operation, the Africa Publishing Innovation Fund, an initiative led by the Genevabased International Publishers Association, turned its attention to the remote learning challenge in Africa. A decision was taken to sponsor locally-owned projects to keep students learning and give disadvantaged communities ways to access books and premises for community cohesion, skills development, studying and reading. The APIF is not the solution, but it is a sincere attempt by publishers to address some of the problems within the overarching African education emergency.
\end{abstract}

Keyword Remote learning · Distance learning - Africa; children · Out-of-school · COVID-19 $\cdot$ Education emergency $\cdot$ Access; Publishing $\cdot$ Innovation

\section{Introduction}

Taking the Africa Publishing Innovation Fund (APIF) into its second year has been fulfilling and edifying in equal measure for all of us working on the project. To describe the APIF as a grant distribution mechanism is not inaccurate, but it would be unfairly reductive and a disservice to the highly committed people involved. By that, I mean the hundreds of applicants who invested time and

Bodour Al Qasimi

bodour@kalimat.ae

1 Kalimat Group, P. O. Box 21969, Sharjah, UAE 
energy in pitching for our support; the team at Dubai Cares, the philanthropic organization that finances it; and the publishers who make up the APIF Committee, who spent long hours sifting and scrutinizing in search of the most deserving and impactful projects.

This year, we are supporting solutions to the dire education challenges in Africa, which have been made immeasurably worse by the pandemic-enforced closure of schools across the continent. As African nations responded to the health crisis, they had to reckon with the dual challenges of shifting to remote learning while cutting education budgets to fund other urgent priorities.

School closures meant countries had to scramble to get more than 250 million students learning online almost overnight.

Even before COVID-19, Africa had 100 million out-of-school children, among the highest numbers anywhere, and the shift to online schooling set a challenge for which many African education systems and governments were totally unprepared.

I asked our 2021 grantees for their views on the situation, and was struck by how the crisis seems to have steeled their resolve to bring overdue change to their countries' education sectors.

'Students transitioning to e-learning methods amid COVID-19 have faced so many setbacks, such as inadequate accessibility to network devices, poor network connections in rural areas, and cost of internet accessibility,' said Kumuriwor Alira Bushiratu, co-founder of the Learners Girls Foundation, on the obstacles Ghanaian students face.

Discussions at two International Publishers Association Africa Regional Seminars, in 2018 and 2019, also highlighted that most African educational publishers and education systems are lagging in implementing digital transformations and adopting new technology. These seminars, held in Lagos and Nairobi, assembled hundreds of publishers, writers, educators and policymakers from more than 40 countries to debate African publishing and seek solutions to its entrenched challenges. They marked a sea change in the IPA's relationship with Africa, and galvanized a more extrospective approach within the continent's book industry.

In the past, publishers and education stakeholders did not prioritize development and provision of accessible digital content, but with the advent of government policies that support inclusive education-coinciding with the pandemic pivot to remote learning-both access and accessibility are now more important than ever,' Will Clurman, Chief Executive Officer of eKitabu, told us.

The situation is further complicated by longstanding issues that have led to insufficient spending on social infrastructure, like libraries, which could have helped students remain in school. Between urban/rural digital divides and long-standing cracks prised wider by the virus, Africa's abrupt shift to remote learning risks creating a generation of children whose inability to access education leaves them far behind or simply unschooled.

In 2019, a partnership between Dubai Cares and the International Publishers Association (IPA) established the Africa Publishing Innovation Fund (APIF) to surface innovations that address many of the access and capacity development challenges that have been thrown into relief by the pandemic. As schools turned 
to distance learning, it was clear to us that millions of African students would be denied their right to an education, and that many would just fall out of the school system.

For this reason, the APIF's 2021 grant cycle sought remote and community-led innovations to keep students learning and provide under-resourced communities with ways to access books and premises for community cohesion, skills development, studying and reading. From more than 300 applications received, we narrowed down the list to five initiatives that targeted three impact areas that we identified as top priorities.

\section{Keeping Kids in the School System}

Evidence from previous pandemics in Africa suggests children without proper support, particularly girls, are at increased risk of dropping out of school. In Ghana, where only $70 \%$ of school-age children are reached by remote education, the APIF has awarded a grant to the Learners Girls Foundation to help 400 at-risk girls in rural communities to continue their education. The grant will go towards linking girls to volunteers to tutor them with school work, as well as mentors, role models and training programs aimed at addressing the imbalance in girls' enrollment in STEM fields.

'Gender equity and disability inclusion in the book sector have traditionally been limited, but addressing these issues during the pandemic is now more important than ever,' said Telesphore Nambajimana, of Save the Children, Rwanda.

\section{Supporting Publishers, Teachers, and Librarians to Shift Online}

Across Africa, policymakers, teachers, publishers, and students have found the shift to remote learning has been complicated by a dearth of accessible digital content. These findings were confirmed by many publishers associations that contributed to the IPA's report From Response to Recovery: The Impact of Covid-19 on the Global Publishing Industry.

Additionally, further studies show that many African teachers were not ready to integrate technology into the classroom and switch to remote learning, and the majority of African teachers received no training as education systems moved online.

'Remote learning is more than providing lessons over the internet,' said eKitabu's Clurman about the urgent need for teacher professional development and continuous support to realize inclusive and quality education. 'For teachers to fully embrace online teaching and learning, they need confidence to create, adapt and deliver content that is accessible and engaging for all learners.'

To address gaps in digital teaching and learning materials and capacity development for teachers and librarians, APIF is awarding grants to eKitabu, in Kenya, and Save the Children, in Rwanda. Starting in East Africa's regional publishing hub of Kenya with plans to scale to 12 African countries, eKitabu will work with 
publishers to enrich the remote learning of more than nine million students and teachers with accessible digital learning materials. Save the Children will train 270 librarians in eight community libraries on the use of technology to strengthen a culture of reading in rural and remote communities while also providing digitally accessible reading materials in Kinyarwanda that will keep 1.6 million children reading while they can't go to school.

\section{Uniting Communities Through Libraries}

Libraries have manifold functions beyond providing access to books: they are centres for studying, gaining employability skills, and even for accessing water. However, resource-poor, rural African communities often lack community libraries.

'Physical [library] structures exist long term and help develop the community through the range of learning opportunities that can happen there,' said Samantha Thomas-Chuula, Head of Programmes at Book Aid International on the importance of libraries in rural communities.

With libraries often the only place to access computers and the internet, students in rural communities face a heightened risk of dropping out of school. A recent study found $89 \%$ of students lack computer access, which indicates how important libraries are in providing the connectivity to keep Africa's rural students in school.

In the Zanzibar semi-autonomous region of Tanzania, Book Aid International will use its APIF grant to transform three shipping containers into fully-equipped libraries with 5,000 books. They will also train librarians to support young people in continuing their studies and the broader community in attaining livelihood skills.

In Zimbabwe, the APIF has awarded a grant to Chirikure Chirikure, one of the country's best-known poets, for the creation of a library in the rural community of Nemashakwe, in the Gutu district. In addition to providing more than 800 youths with access to books and computers, a water source will also be bored for the library users. The water source will also reinforce community solidarity and encourage more library facility use.

'At the Nemashakwe rural centre, the nearest source of water is about a kilometre away. There is no electricity and internet. With APIF's help, we will also be able to install a solar power system at the library, and hook up to the internet through a mobile phone network. The library will not only connect learners to information, it will become a centre that connects and empowers the entire community,' said Chirikure Chirikure about the need for providing basic community necessities in addition to books as part of its initiative. 


\section{Translating Publishing Ecosystem Challenges into Innovation}

As the IPA has documented, publishers globally moved quickly to help school systems transition to online learning, fast track critical research, and provide an escape at a time of unprecedented crisis. The initiatives that the APIF sponsors are proof of the way publishers are also innovating on the ground in the most challenging environments and circumstances. APIF's grant recipients are a testament to the value of publishing in working with teachers, libraries, governments, and civil society to innovate through challenges and turn adversity into innovation-led opportunity.

Publisher's Note Springer Nature remains neutral with regard to jurisdictional claims in published maps and institutional affiliations. 